\title{
Classism, Casteism and Sexism a Curse in the Life of Dalit Women: A Social and Literary Analysis
}

\author{
Ambreen Safdar Kharbe ${ }^{a, *}$ \\ ${ }^{a}$ College of Languages and Translation, Najran University Najran, Kingdom of Saudi Arabia. \\ *Corresponding author Ph: +966552648818; Email: ambreenkharbe72@gmail.com ; askharbe@nu.edu.sa \\ DOI: https://doi.org/10.34256/ijll2115 \\ Received: 28-03-2021, Revised: 30-03-2021; Accepted: 30-03-2021; Published: 30-03-2021
}

\begin{abstract}
Class, caste and, gender systems prevail since ancient times in society. Lot has been said and studied about it but yet society is not free from these stigmas. The division of society on the basis of class, caste, and gender has hindered the progress of society at the same time has treated the lowest castes also known as Dalits or former 'Untouchables' as underdogs and have tremendously ill-treated this section in the society. The mainstream has made them marginalized and unheard. Dalit women are triple victims and are the most sufferers in Indian community. Though the Indian Constitution talks about equality, freedom, and justice to all Indian Citizens, irrespective of caste, class, creed, religion, and sex there are many who are not privileged for the same. This research paper focuses on the understanding of class and caste system with addition to Dalit women as the triple victim of class, caste, and gender with the background of social structure in India and Dalit and Non-Dalit writers unveiling their plight and sufferings. Select works of major writers such as Mulk Raj Anand, Munshi Premchand, Mahasweta Devi, Urmila Pawar, will be considered for this research. The research makes the unheard voice of Dalit women reach the masses and ignite the spark of justice and respect for them in society.
\end{abstract}

Keywords: Class, Caste, Gender, Dalit (Women), Injustice, Sufferings, Ill-Treatment

\section{Introduction}

The class system is a universal observable fact practiced all over the world. It denotes a society categorized into groups on the basis of economic status. According to Karl Marx society is divided into two major classes - the bourgeoisie and the proletariat which came into existence in the seventeenth century with the advent of the industrial revolution. Further, Andersen Margaret and Taylor Howard (2017, p.154) opines about Karl Marx's conflict theory "a dominant class as controlling the resources of society and using its power to create the institutional rules and belief systems that support its power." Karl Marx is better known as 'The Father of Conflict Theory' focuses on insight regarding the inequality and the conflicts that exist between socioeconomic classes. Bourgeoisie, a minority in the population system is a group of people in the society who hold the majority of wealth and other means whereas the proletariat, majority in the population are the working class and poor. This working class is caught under the power system of Bourgeoisie and is helpless in front of their tyrannical behavior towards them. A handful of elite class is able to dictate the entire society just because they have a huge amount of control over resources and power. Many scholars view that socioeconomic society is divided into a hierarchical system based on occupation, economic status, and income. Max Weber a German sociologist, philosopher, jurist, and political economist formed a three-component theory of stratification in which social difference is determined by class, status, and power. According to Max Weber, the class structure is based on birth and individual achievement related to the economic position in society, status based on person's prestige, popularity, and social honor whereas power attributes to the chance of an individual in a social relationship can achieve and the ability to get their way despite the resistance of others. According to Marxist theory, a class is a group of people defined by their relationship to the means of production. In the current context relationship, love, respect, humanity all depends on class status. Even the same blood wants to keep ties with their kinship depending on class status. In India right from the zamindari system and feudal lord system to today's entrepreneurs who have covered world markets has 
always ignited and kept alive the social stratification in the society with their powers. The feeling of superiority among the elites has made the poor feel low and believes in inferiority. At the same time, class status of an individual can be changed with education, economy, and power and is strongly influenced by the lifestyle. Classes are not static entities but are rather regenerated through production processes.

\section{Casteism in India}

A caste system is a social stratification in which castes are hierarchically organized and separated from each other by rules of religious norms. Historically and traditionally, one of the most complex systems of segregation and discrimination witnessed is the caste system in India.

The word "caste" has its roots in Portuguese seafarers who traded mainly on the west coast of India in the 16th and 17th centuries. It was taken from the Portuguese word "casta" meaning "species" or "breeds" of animals or plants and "tribes," "races," "clans," or lineages" among men. But the traditional caste system of India existed 3000-4000 years ago when Aryan-speaking nomadic groups invaded this country and migrated from the north to India. Aryans destroyed the past glory of unity of the natives of India and sowed the seed of color and racial superiority over the natives. They divided the Indian society into four Varnas i.e. Brahmana, Kshtriya, Vaishyas, and the rest were called Avarnas i.e. Panchamas i.e. untouchables. Sometimes between 200 BC and 100 AD Laws of Manu known as Manusmriti was written by Aryan Priests. They revealed that Brahamana, Kshtriya, and Vaishyas are of Aryana origin whereas Shudras and the Panchamas are the natives of India. Manu Laws denied Shudras from all the privileges like rituals, education, dignified professions, and social mixing. These divisions still survive today and have a drastic effect on the lives of Shudras. A well-known historic incident of Ekalyavya, a Shudra who has to sacrifice his right thumb for learning the teachings of teacher Drona in Mahabharat (Ekalyavya learned archery hiding from Drona when he used to teach Prince Arjun because being Shudra Ekalyavya was not allowed to learn and opt another profession beside what caste system has destined to him).

After the Aryans, the Hoons, the Mangols, the Greeks, and the Muslims invaded India followed by the takeover by Britishers. But the life of Shudras also known as Untoucahbles/Dalits didn't improve. During British time many reforms took place against the evil practices in India such as Sati System, Child Marriage, and Widow remarriage but the issues of Dalits remain intact. After revolution, the upper castes Hindus got demanded a share in British Administration but the natives Shudras share was negligible. Mahatma Gandhi called Shudras as "Harijan" means close to God. Dr. Babasaheb Ambedkar, a Shudra was a learned person, Chairman and Draftsman of the Indian Constitution has suffered a lot due to this religious segregation. Rulers have changed centuries across but the plight of Dalits still prevails in Indian society. Indian Constitution lays great emphasis on justice, liberty, equality, and fraternity in the following articles (The Constitution of India, 2021):

Article 15 (i) states - "The state shall not discriminate against any citizens on grounds only of religion, races, caste, sex, place of birth or any of them".

Further Article 12 (ii) states - No citizen shall, on grounds only of religion, race, caste, sex, place of birth or any of them, be subject to any disability, liability, restriction or condition with regard to - (a) access to shops, public restaurants, hotels and places of public entertainment; or (b) the use of wells, tanks, bathing ghats, roads and places of public resort maintained wholly or partly out of State funds or dedicated to the use of the general public.

But in reality, these articles are not practiced in India. Dube comments - "India's 'caste' system has much been criticized, both at home and abroad (Dube, 1966:59). Yet Varna and Jati have had extra-ordinary durability and resilience; they appear to survive in some form or other all the assaults on them".

\section{Dalit Movement, Dalit Literature and Dalit Feminism}

In India under Hindu caste system comprises the lowest class known as Shudras. Degrading words such as Chamar, Mahr, Mang, and Paraiyar are used for them in a dehumanizing manner. These castes of people are also known as Dalits or Untouchables. The term 'Dalit' is not a new term rather it was used in the 1930s by the British as a Hindi and Marathi translation of 'Depressed Classes' which is now called Scheduled Castes. In 1948 Dr. B.R. Ambedkar used the term 'broken men' as an English translation of Dalit in his speeches. The Dalit Panthers revived 
the term and in their 1973 manifesto expanded its referents to include the Scheduled Tribes, 'neo-Buddhists, the working people, the landless and poor peasants, women, and all those who are being exploited politically, economically, and in the name of religion' (Omvedt, 1994, p. 72). The 1881 Census of India described Varna categories, Dalit jatis at or near the end of the lists. The 1891 Census, adopted a more political and standard classification of castes according to the occupation. Thus Dalit castes were included within such occupational categories as field laborers, leather-workers, scavengers, watchmen, and village menials. The 1901 Census classified Hindu castes in order of social precedence 'as recognized by native public opinion' (Pradhan, 1986, p.197). Despite the protective policies such as educational concessions and scholarships, employment and political reservations as well as socio-economic welfare benefits given by the government under the provisions of the constitution Dalits are still socially and economically weak and politically powerless. The term 'Dalit' thus describes a condition of being underprivileged and deprived of basic rights and refers to people who are suppressed on the ground of their lowly birth. The word 'Dalit' is a descriptive word evocative of bondage and agony, the anguish and frustrated aspirations of a vast victimized section of the Indian population right down the ages. (S.M. Michael, 2007:108)

Untouchability has long been considered as a social evil and much effort has been made to eradicate it from its roots. Religious and social reformers like Gautam Buddha, Ramajuna, Ramanand, Chitanya, Kabir, Nank, Tukaram have made great efforts in eradicating it but unfortunately couldn't succeed it much extent. The Brahmo Samaj, the Arya Samaj, and other social organizations did much to secure for them social, religious, and cultural equality. In 1923 Gandhi founded All India Harijans Sevak Sangh and started numerous schools and residential vocational schools for them in order to upgrade this community and give them equal status in the society.

Dr. B. R. Ambedkar the most well-known Dalit leader represented the Dalit community during the colonial era, carried out a social and political war against untouchability after independence too. Today most Dalit movements believe themselves as heirs to Ambedkar. Dalit youths inspired by the Black Panthers of the United States called themselves Dalit Panthers. They started the cultural and literary movement in Maharashtra in 1972 which was later transformed into a political movement. Dalit movement varied from leaders to leaders. Some Dalit leaders followed the process of 'Sanskritization' to elevate themselves and consider themselves equivalent to the high rank of caste hierarchy. They also adopted Brahmin's mannerism. To end up the torture of untouchability they believed to discard Hinduism. Thus we have a historical record that many Dalits converted to Christianity, Sikhism, and Buddhism.

Dalit Literature is an extension of Dalit social and political movement. Dalit Panthers movement led to the emergence of modern Dalit literature in Maharashtra in the early 1970s. Dalit literature existed in multiple vernaculars. Arjun Dangle's "Poisoned Bread: Translations from Modern Marathi Dalit Literature" (Dangle, Arjun, 1992) the first edited anthology in English made Dalit writings reach across the globe. Dalit literature aims at creating awareness about Dalits, Dalits as a social institution, and their plights to the world. Mulk Raj Anand was the first to write about Dalits in his novels like Untouchable and Coolie (Anand, Mulk Raj, 1981). Dalit poetry expressed the violent experiences of dalit's life. Poets like Keshav Meshram, Daya Pawar, Namdeo Dhasal took Dalit Poetry to heights with grave concerns and aesthetically. Dalit folk poetry shrouded the burden of creating awareness about Dalit reform movements. Short stories and novels as an important genre exploited Dalit sensibility more pertinently. Dalit Autobiographies moved the world knowing about their tragic lives. Dalit writings portray marginalization, protest, and revolution. It is studied as charismatic writing not only in Indian Literature but also in World Literature.

Dalit women/feminist didn't lack behind to represent their community through an artistic ladder. Autobiographies became the most convenient tool to express themselves. Women writers like Shantabai Kamble, Urmila Pawar, Baby Kamle, and others heralded the literary scene with social and humanistic consciousness (Kamble, Baby, 2009). They explored in their writings as a triple victim of class, caste, and gender. Dalit feminists argue that women, and in particular Dalit women are the worst sufferers in society. They are dual victims of both casteism and sexism. Dalit women largely capture the picture and experiences of individual Dalit women sufferings as marginalized unheard voices in a larger social context. The movement of Dalit feminism can be traced back in the writings of Jyothiba Phule who voiced against patriarchy and women's oppression. Just like Black feminism, Dalit feminism writes and talks about women's emancipation. National Federation of Dalit Women founded in 1995 
in New Delhi is a step paving the paths to the entire Dalit women community. Henceforth, much more such organizations came into existence to deal with the notion of equality and fight for their rights. "The concept of Dalit feminist standpoint is derived from the concept of 'standpoint theory', which refers to a feminist school of thought born from Marxism, arguing in favor of the production of knowledge that stems from social epistemological positions. Dalit feminist standpoint refers to a spectrum of knowledge consisting of individual testimonies of marginalized women's experiences within the larger social structures." (feminisminindia-Guest Writer). The major viewpoint of Dalit feminists was multifold in nature - firstly, how Dalit women were focused at initial level in women's movement in India and secondly to focus on Dalit women's experiences and life testimonies, and finally, Dalit women agitation against marginalization in literary, political and social circles. Dalit women have been raucously mobilizing to pen down their sufferings through their own writings and stories.

\section{Classism, Casteism And Sexism: A Literary Analysis}

Women are the most oppressed section in society though demographically they constitute nearly half of the population. Since ancient times writers, saints, social activists have shown their concern about it and have propagated to eradicate it. Women perform two-thirds of the world's work hours but still are poorer in resources and are not made a part of decision-making. According to Jeanne Vikers (Jeanne Vikers, 1991:p.15), "when we speak of the 'poorest of the poor', we are always speaking about women. Poor men in the developing world have even poorer wives and children". Women along being a good house care-taker actively participate in shouldering worldly affairs. Like Black Women victims of race and gender, Dalit Women are the dual victim of caste and gender. Besides this twofold victims class oppression goes hand in hand. As Dalit Literature attempts to articulate unheard, unspoken voices of Dalits, writers have portrayed their sufferings, torment, experiences, and consciousness. The writings represent the struggle, protest of the underdogs of the society for their rights, liberty, honor, security, and freedom and more importantly projection of Dalit Women.

Mulk Raj Anand was the first non-Dalit writer to write about the plight of Dalit's life in his novel Untouchable (Anand, Mulk Raj, 1981). Though the novel deals with male protagonist Bhaka and the story revolve around this main character, Anand didn't fail to depict the lives of Dalit Women. Sohini, sister of Bhaka though a minor character in the novel is the epitome of Dalit women. She contributes as a resourceful person to the family. She does household work, fetches water from the well, brooms, and sweeps the temple. But being an outcast Sohini and her family has to depend on high-caste people for their bread and butter. Being a Dalit/outcast automatically lowers their class status as they cannot opt for any other profession to raise their status in society. Getting water from the well was the most difficult task for them. Dalit women were not allowed to draw water; they have to depend on high-caste for getting water which is one of the basic needs. One of the other one of the character Gulabo, a washerwoman is shown as a jealous woman for Sohini. She attacks her verbally using derogatory words for her such as bitch and prostitute. This reflects the anguish of Dalit Women as they cannot spout out in front of any other, neither in front of their male counterparts nor in front of any other section of the society. The novel also portrays the evil custom of untouchability of outcaste to high-caste. Sohini, a patient and sympathetic character tries her best to help her brother Bakha in all possible ways and does a better job than him. But she is never appreciated by Bakha. She also faces the anger and humiliation of her father Lakha who calls her out with derogatory words such as 'daughter of a pig'. She is the most vulnerable person in the house. Along with the ill-treatment and ignorance of her own family members, she also suffers hatred from Gulabo. Besides this Sohini becomes a victim of molestation through high-caste Brahmin Pundit Kali Nath. Sohini catches Nath's eyes, the time she was waiting to fill the pitcher with water. He gets attracted by her beauty and tells her to come closer to him with the excuse of giving water from the well. He orders her to come to the temple later in the day to carry out cleaning and sweeping and at the same time sexually abuses her. In this situation rather than becoming a comfort zone to his sister, Bakha holds Sohini responsible for the whole ignominy. This leads to subalternity and powerlessness with regard to women. Female sexuality is supervised in society whereas men are left free to show their non-controllability in matters of sexual desire. Further, the novel also portrays the control on every act of happiness of women. Sohini is expected not to laugh or show her teeth because this act is considered as belittling and accepted act only by prostitutes. Consequently, girls gradually become quieter, passive, and submissive whereas boys are assertive, confident, and sure of themselves. 
Further, Anand reflects another most important institution of marriage in his novel. He focuses on the marriage of an Indian girl, belonging to the lower class with a total stranger and in early adolescence. In this context, Jyoti Puri expresses her view on the hegemonic aspects of marriage in a woman's life in the following lines:

"From a cultural standpoint, marriage and motherhood are considered the primary gender roles for women across social classes...To the extent that these statuses are considered normal and essential aspects of adult womanhood, they also serve to limit and regulate women's lives." (Jyoti Puri, 1999:136)

In Untouchable, Ram Charan's sister is married off at a very tender age of fourteen and is expected to be docile, well-mannered, obedient, and submissive housewife to her husband. Sudhir Kakar states a few reasons behind this odd practice:

"The custom of early marriage recognizes and is designed to guard the promiscuous resurgence in adolescence of a girl's playful childhood sexuality and the threat this would pose to Hindu social organization." (Kakar, Sudhir, 1988, p.52)

Thus, Sohini, Gulabi, and Ram Charan's sister in Untouchable are victims and the most vulnerable and subaltern lot in the society.

Mushi Premchand's most well-known short story "The Shroud" talks about the deplorable condition of Dalits. The story depicts the harshness, bleakness, and dreadfulness of the two characters Ghisu and Madhav, and their plight faced due to class and caste structure in the society. They belong to the 'chammar community' the lowest among the untouchable castes. The story went into controversy objecting to Premchand's depiction of chammars through Ghisu and Madhav as a representative of their caste in derogratory way. They do not even have sufficient food to feed their stomach daily. Budhia, Madhav's wife is shown in labored pain; rather than going and helping her by taking her to the doctor or calling any other woman for help; they are waiting for her to die so that they can sleep in peace. Here projection of Bhudia is a real matter of concern. She is being tormented from all the perspectives of class, caste, and gender. She is totally dependent on her husband or male members of the family. Due to her class and caste status, no one is beside her to take care of her and help her in the most difficult situation. Besides, her husband who is supposed to take care of his wife in all situations is heedless. He is least bothered about the pain of his wife and is taking pleasure in eating a roasted potato with his father which they got to eat after two days of hunger. After eating they leave Bhudia to moan in pain and die. As expected they both see her dead in the morning. Premchand here later portrays the gruesome atrocity related to the shroud of Bhudia. As per norms, high caste people will offer money to carry on funeral rites. Within an hour they succeeded in collecting five rupees for the funeral. First thing was to buy a shroud for the deceased. Instead of getting shroud and performing the funeral both father and son spend the money in eating, drinking, and merry- making, and eventually falling down in a drunken stupor. Budhia's representation is an epitome of invisible violence inflicted by the dehumanizing effect of class, caste, and sex. Budhiya has served her husband and father-in-law when alive and even her death served them by giving them chance to exploit her by earning extra buck at the cost of her life. Budhiya is been exploited during her lifetime by shouldering all the responsibilities of home in the presence of male members and is also exploited after her death.

Besides Mulk Raj Anand and Munshi Premchand, Mahasweta Devi is another non-Dalit writer who has successfully projected the pain and anguish of Dalits with a special focus on Dalit women. Her intimate connection with Dalit and Tribal communities allowed her to understand and document issues at the grassroots level. Her writings focus on subaltern politics with the projection of unheard and unexposed exploitation. In an article, "The Story of Chuni Kotal" in Dust on the Road Mahasweta gives an account of real-life incident of Chuni Kotal (Mahasweta, Devi, 2000a), who committed suicide, a girl of 27, from Lodha tribe, the first graduate woman among the Lodha Savara and Kheira Savara of West Bengal. She is subjected to sheer injustice and callousness by the university authorities that make her end up her life (Mahasweta, Devi, 2000a). The Lodha tribe was once labeled as 'criminals' by the Britishers but were de-notified in the 1950s. However, mainstream society still looks at them as criminals and does not spare a chance to humiliate them. Mahasweta Devi in an article, "Lodhas of West Bengal," in Dust on the Road writes: 
The term 'criminal' may not have been tagged on to the tribe in the records, but the treatment meted out to them is so insulting and dehumanizing that such official clemency becomes an absurdity (Mahasweta, Devi, 2000a).

Chuni's life is made miserable by the department authorities at university by making her work continuously without any break throughout the day as well as she suffered from denial of any holiday. She was even accused of her character. Her plea for transfer was also denied. During her M.Sc in Anthropology, she was taunted and humiliated by a male professor. She was deprived of giving her exams for purposely showing her as a defaulter in attendance. Later when she is allowed to appear for her exams she is purposely failed. Her life could never be at peace. To make her life worst the district officer filed a complaint about leaving the hostel and joining university. Her complaint to the Education minister for justice fell on deaf ears and her repeated cries and struggle went unheard. Finally, unable to bear it anymore she narrates her disheartening saga to a few of her co-students before committing suicide on 16th August 1992. Her suicide is the picture of the brutal tyranny of politics of caste, class, and gender. In this regard Mahasweta Devi asserts:

Chuni's death has revealed what West Bengal truly is. Brutal caste and class hostility and persecution has been allowed to continue . . . nothing was done to . . . throw out the caste baiter. ... A new kind of hunt. West Bengal has the same caste and class hatred, but the methods are sophisticated and complex, that is the only difference with other states. The curse of the babu culture runs in Bengal's veins. West Bengal forces a Chuni Kotal to commit suicide and goes ga-ga over the nauseating display of a 'Sutnati Utsav,' celebrating three hundred years of the city of Calcutta. (Mahasweta, Devi, 2000b, p.142)

Thus, Chunni's life and death are a real-life projection of how society treats underprivileged section of society.

Mahasweta Devi's portrayal of another oppressed Dalit woman Dhouli in Dhouli, is a powerful illustration of the suffering faced by Dalit women due to class, caste, and gender. The story revolves around the young widow protagonist Dhouli who suffers from extreme exploitation. She is all alone without her brother, father, or husband to take care of her. The protagonist Dhouli belonging to an untouchable community lives with her mother in Taharr. Dhouli's father used to till the land and work as a bonded laborer for Misras. After her father's death Dhouli's mother was deprived of tilling the land, thus was deprived of the only source of income for both women Dhouli and her mother. Belonging to the lowest section of the society and prey of caste, class, and gender they both grazed the goats and swept orchards of the Misras. Misra's son Misrilal traps Dhouli in love and impregnates her. However, later with the fear of family he denies the whole affair and held Dhouli guilty of it. Falling in love and bearing a child of high-caste and class was a grave sin against her. She is isolated in her village and denied food. In the start, they both survived eating roots and tubers in the forest and child with scraps and scrapings. Finally, left with no alternative to survive and take care of three lives Dhouli takes prostitution. Life for Dhouli is not less than a curse.

Urmila Pawar, an activist, and award-winning Dalit Woman writer recounts the struggle of three generations of Dalit Women and the way they overcome the burden of their caste torture. Pawar grew up on the rugged Konkan coast, near Mumbai, where the Mahar Dalits were housed in the center so that the upper-caste can summon them at any time as per need (Pawar, Urmila, 2009). Pawar however, left Konkan for Mumbai to pursue her education and later became a prominent figure in Dalit literary movement. Her autobiographical novel The Weave of My Life is not only a memoir dealing with the tireless efforts to get through hideous tragedy in her life but also conveys a sense of awakening consciousness of profound political and social change. Like Chaucer's Canterbury Tales narrating tales on the way to the pilgrim, Dalit women in The Weave of My Life tell stories to female companions on their way to and fro from village crossing mountains to town to sell firewood and buy salt and dried fish on the way back to home. The tale during this strenuous journey portrays the drastic difficulties faced by them in their life. The harshness of their lives is projected by different characters in the novel. One mother character in the novel remembers that she has left her milking child at home as milk rushes to her breast. The other projection is of children in context to Pawar remembering her trip to her grandmother's village. The unending barefoot journey, the scorching sun, blisters in children's feet, and tying up of leaves in place of shoes is a soul-taking experience of Dalits. Pawar further describes how the tiger's roaring scared the womenfolk in broad daylight. They used to even encounter venomous snakes and thorny bushes in the jungle. Walking through dense 
forest with risk of life they cursed their ancestors. After returning home they have to be energetic for preparing food for their family members and taking care of children. Like African-Americans, Pawar too was inspired by oral narration tradition and captivated the method of telling stories from these women folks. Pawar also describes superstition and religious beliefs in the village. The incident of women who could not conceive, their husband's marriage with their wives' sister, and further the impact of baba proving the one who could not conceive as a possessed woman is a disheartening tragedy in their life. Illiteracy and ignorance have made women of the Dalit community the victims of blind faiths. The superstitious nature of the society is depicted artistically by Pawar.

Pawar's autobiographical novel is a delineation of her struggle sometimes as a Dalit or other times as a woman in a caste-based society. It further investigates how class, caste, and gender differences have been spread up in society. The novel is a quest for self-identity, social equality through the most revolutionary weapon literature.

Baby Kamle's autobiographical narrative The Prison We Broke is a clear pictures of the spaces allocated to Dalits and high-caste Hindus in the society. The depiction of their brush-out clothing and stale food in the form of alms is heart-breaking. Differentiating between the autobiographies written by the upper-caste women and Dalit women Gopal Guru in his afterword to The Prisons We Broke, states that "the narratives of the former were about their confinement and discrimination within the four walls of their homes, while Dalit women have spoken out about both the home and the world" (Gopal Guru, 1995, p.159).

Kamle was a staunch follower of Dr. B.R Ambedkar and followed his path and principles right from the early age of her life. Kamble didn't have the courage to publish her work/autobiography, and so she kept it hidden from her husband and son and was finally published twenty years later it was actually written. Kamble says "I used to be scared of both my son and my husband, scared of their reaction. My husband always called me an ignorant woman! I was afraid of his response. So I kept everything hidden away from their eyes for almost twenty years." (2009:147) The same long-life humiliation and torture of begging for food by Dalits from the upper-caste are well expressed in her work. She further documents Ambedkar ideology and the Ambedkarite movement. She critically pens down Dalit's patriarchy and the violence suffered by the Dalit women in families. The Major part of the autobiography is a general description of the Mahar community where readers are unable to locate Baby Kamle in particular. Her identity can be located through her active participation in the Ambedkarite movement. For Kamble her suffering was an epitome of community suffering, at the same time community sufferings were her own pain. The inhuman act of the society of upper-caste is well described. She writes "The only food that is available for Mahars was the dead cattle and sometimes the rotten dead cows offered by the upper castes of the village." (2009:12)

Mahars are deprived of medical and health benefits and as usual, women are the most sufferers. Women are tortured and left almost to die during their childbirth. No medical facilities are provided to them; in addition, they become victims of superstitious beliefs as if they are possessed women. Their rate of survival is very low. Moreover, "The godman of the village does exorcize and kills the people by torturous methods such as beating them and strangling them. These deaths are perceived to be the murders committed by the evil spirits." (2009:80) Kamle very accurately and minutely describes the pain of the Dalit women in their families and in society. Dalit women are victims of untouchability, poverty and patriarchy which mean caste, class, and gender. Kamle rightfully writes:

"Everyday the maharwada would resound with the cries of hapless women in some house or the other. Husbands, flogging their wives, as if they were beasts, would do so until the sticks broke with the effort. The heads of these women would break open, their backbones would be crushed, and some would collapse unconscious." (2009:89)

She further highlights another grave issue of marriage. Dalit women are married when they are a small girl that is at the age of eight, suffer from physical violence at the hands of their husbands, and do not have the freedom to seek divorce on their own. The abandoned wife has no shelter for her and is treated appallingly in society. In a way, Kamle criticizes the way in which Dalit women are treated by their own men and society. 
Meena Kandasamy is yet another Dalit Women voice known as 'Angry Dalit Voice'. In one of her poems entitled "Shame" the poet describes the fate of a gang-raped girl who fails to get justice in society because she was a Dalit. For the victim, death is the only option she can embrace to get rid of harassment and sexual crimes.

\section{Classism, Casteism And Sexism: A Social Analysis}

Dalit women are thrice discriminated against the ground of untouchables or outcaste, caste-faced gender discrimination, and economically impoverished due to unequal wages, low or unpaid labor. Of the total population, Dalit women constitute $16.3 \%$ of which $18 \%$ of women live in rural areas performing hard domestic labor or unpaid agricultural laborers. The process of globalization has affected Dalit women radically. This has further led to poverty and driven them to the sex trade business. The health condition of Dalit women is a matter of thought as it records high maternal mortality and infant mortality. The majority of Dalit women are illiterate. There is a high rate of drop-out of Dalit girls from school as they are forced to work as child laborers. Dowry, the evilest practice of society that was not practiced by Dalits has now become a bane due to Sanskritisation that is practicing rituals and customs of Hindus/upper-caste. They are deprived of active participation in politics. The places where Dalit women have tried to consent to parliamentary elections were attacked brutally. Despite the existence of Constitution of India, Dalit women are the most disadvantaged and vulnerable lot in society. At the same time, there are few instances where Dalit women have been nominated as a local governing body called Panchayat.

The history and existence of torture on Dalit women abounds in many. They are vulnerable to genderspecific abuses such as rape, stripping, and naked parade. There are various cases of atrocities committed against Dalit women. The gruesome incidents which took place in the lives of Dalit women can be unveiled below to understand the status of Dalit women in society.

Rajasthan Dalit social worker gangraped -January 24th, 2006:

30th December 2005 a heartbreaking incident took place in Rajasthan with Anganwadi worker Bahnwari Devi, a 25 years old Dalit woman. Instead of helping her, the police declared her mentally unstable and pushed her to a psychiatric clinic. According to FIR, she was raped by five, out of which three were her supervisors. Her husband was told after three days that she had been admitted to hospital due to her mental breakdown. She was involved in social activity in uplifting the women regarding personal hygiene, family planning, benefits of girl's education, and campaigning against social ills like female foeticide, infanticide, dowry, and child marriage. The accused five were arrested for their crime after more than a year. This rape incident of Bhanwari led India to pass and implement 'Sexual Harassment Law'.

Uttar Pradesh Dalit girl, victim of brutal gang rape, dies in Delhi hospital- September 29th, 2020:

The 19-year old Dalit girl from Hathras village in Uttar Pradesh was brutally assaulted by four upper-caste men and later strangulated and dragged with her dupatta. She was succumbed to multiple injuries and was admitted to Safdarjang Hospital in New Delhi. Speaking to the newspaper 'The Hindu' the victim's brother gave the statement - "Though there is a dominance of one caste in the village, I came to know about my sister being targeted by these men only when she recorded her statement. They told her if she didn't submit to their 'demands', they would shoot her brother dead". (The Hindu: 29/09/2020) Unfortunately, the girl couldn't take the violence and breathed her last.

Besides this, there are many more such instances such as - Three Dalit women from Muktsar in Punjab have opened up and have charged the police for torturing them in an animalistic way which includes administering electric shocks to their 'private parts'. Another bizarre incident deals with Uttaranchal-based doctor who was charged to rob a Dalit woman's kidney. An added example can be seen in the Jharkhand village where a 50-year old Dalit woman was paraded naked for allegedly selling a 12-year boy two years back in Uttar Pradesh. A 15-year old Dalit girl was burnt alive when she was sleeping at her home for the crime of not dropping the charge filed against upper-caste youth for raping her. There are such innumerable Dalit women victims of high-caste and patriarchal society. 


\section{Conclusion}

The classification of society on the basis of class, caste/race, and gender is the most dehumanizing act existing in this world. Division of the society on this basis has created havoc in the life of marginalized, subaltern, and vulnerable sections of the society. The splitting up of haves and have-not has resulted in the privileged and deprived segment in the society. This deprived sector is a further victim of caste. In India, the caste system is a curse on the one belonging to the lowest system known as Dalits. The inhuman torture and agony are leveled on them despite Constitution declaring equal rights and freedom to all irrespective to caste, creed, and sex. Despite the Constitutional mechanism, wherein the preamble of Indian Constitution states "WE, THE PEOPLE OF INDIA, having solemnly resolved to constitute India into a SOVEREIGN SOCIALIST SECULAR DEMOCRATIC REPUBLIC and to secure to all its citizens: JUSTICE, social, economic and political; LIBERTY of thought, expression, belief, faith and worship; EQUALITY of status and of opportunity; and to promote among them all FRATERNITY assuring the dignity of the individual and the unity and integrity of the Nation," the condition of Dalit Women is the worst. NonDalit writers have successfully portrayed their repressed and passive status. The autobiographical works of Dalit women writers, The Weave of My Life and The Prisons We Broke are the pen-picture of Dalit women's lives, struggles, oppression, endurance, and standpoint. On the other hand, live incidents of Bhanwari Devi and Hathras girl reflects the gruesome situation in the society with regard to Dalit women. Their life is a never-ending curse through which they are unable to come out and see no bright rays in the future. Survival and prestige are still a matter of concern with regard to Dalit women. Dalit feminists redefine feminism by introducing the category of 'Dalit' in the core feminist thought; thus, adding caste to its study and praxis and rethink Indian feminism from a new perspective.

\section{References}

Anand, Mulk Raj. (1981). Untouchable. Arnold Publishers. New Delhi.

Andersen, Margaret, and Taylor, Howard. (2017). Sociology the essentials. Cengage Learning. USA.

Dangle, Arjun. (ed). (1992). Poisoned Bread:Translation from Modern Marathi Dalit Literature. Orient Blackswan. New Delhi.

Dube, S.C. (1996). Indian Society. National Book Trust. India.

Guru, Gopal. (1995). 'Dalit women talk differently'. Economic and Political Weekly, 14-21 October, 2548-2550.

Kakar, Sudhir. (1988). 'Feminine Identity in India' In Ghadially, Rehana (ed), Women in Indian Society. Sage Publication. New York.

Kamble, Baby. (2009). The Prisons We Broke (Trans. Pandit, Maya). Orient Blackswan. New Delhi.

Mahasweta, Devi. (2000a). 'Lodhas of West Bengal'. In Dust on the Road: the activist writings of Mahasweta Devi, ed. Maitreya, Ghatak. Seagull Books. Calcutta.

Mahasweta, Devi. (2000b). 'The Story of Chuni Kotal'. In Dust on the Road: the activist writings of Mahasweta Devi, ed. Maitreya, Ghatak. Seagull Books. Calcutta.

Michael, S.M. (2007). Dalits in Modern India Vision and Values. Sage Publications. New Delhi.

Omvedt, Gail. (1994). Dalits and the Democratic Revolution: Dr. Ambedkar and the Dalit Movement in Colonial India. Sage Publications. New Delhi.

Pawar, Urmila. (2009). The Weave of My Life A Dalit Women's Memoirs, (Trans. Pandit, Maya). Columbia University Press. New York.

Pradhan, Atul. Chandra. (1986). The Emergence of the Depressed Classes. Bookland International. Bhubaneshwar.

Puri, Jyoti. (1999). Woman, Body, Desire in Post-colonial India, Narratives of Gender and Sexuality. Routledge. New York.

The Constitution of India - Available: https://www.india.gov.in/sites/upload files/npi/files/coi part full.pdf Accessed on 20th January 2021. 
Vickers, Jeanne. (1991). Women and World Economic Crisis. Zed Books Limited. London.

\section{Funding}

No funding was received for conducting this study.

\section{Conflict of interest}

The Author has no conflicts of interest to declare that they are relevant to the content of this article.

\section{About the License}

(C) The author 2021. The text of this article is open access and licensed under a Creative Commons Attribution 4.0 International License 